\title{
Integrating Assessment and Performance Measurement: A Case of an Academic Course for Quality Improvement Actions at a Saudi University
}

\author{
Khalid Mohiuddin (i) 1,*, Mohammad Aminul Islam ${ }^{(1)}$, Shahrear Talukder ${ }^{(\mathbb{D})}$, \\ Mohammed Alghobiri@1, Mohamed Nadhmi Miladi ${ }^{1}$, Ahmed Abdelmotlab Ahmed 1
}

${ }^{1}$ Management Information Systems, College of Business, King Khalid University, Abha, Saudi Arabia.
${ }^{2}$ Department of English, Bangladesh Army University of Science and Technology, Nilphamari, Bangladesh

\section{ARTICLE HISTORY}

Received: Oct. 22, 2019

Revised: May 24, 2020

Accepted: Aug. 09, 2020

\section{KEYWORDS}

Course assessment, Higher education, Performance indicators, Rubrics,

Performance evaluation

\begin{abstract}
This study aims to assess and measure students' performances using course-key performance indicators (course-KPIs) in an academic course at a Saudi university. The approach includes three aspects of assessment (i) integrating course components and correlating course learning objectives with the program learning domain, (ii) course evaluation using rubrics, and (iii) performance mesurement using a scientific method. Moreover, it presents a novel approach for performance measurement of the course learning skills. In this study, a course has been taken to demonstrate how the KPIs are measured for evaluating students' performances. This approach relies on several specific documents that are developed for the course delivery by following the National Qualification Framework (NQF) in Saudi Arabia and the guidelines of the Accreditation Board for Engineering and Technology (ABET). The performance evaluation outcomes are useful indicators that guide the teachers to improve course learning skills. It also helps the teachers in the quality delivery of the courses and ensures continuous improvement in learning and teaching. This study concludes with an emphasis on the measuring performance using course-KPIs which can be adopted for quality improvement for any academic course in higher education irrespective of data size.
\end{abstract}

\section{INTRODUCTION}

Evaluating and measuring students' performance properly in an academic course remains a major concern for higher education institutions (Aoudia et al., 2015). Assessment of an academic practice during a course delivery is one of the essential aspects of students' performance evaluation (University of Technology Sydney, 2010). The course performance evaluation outcomes are useful indicators for the teachers to improve the quality of learning and academic practices. Douglas \& Hines (2011) discussed assessment practices, the importance, need, and the complexity of the assessment process in achieving the desired outcomes.

CONTACT: Khalid Mohiuddin $\square$ Official email ID: kalden@kku.edu.sa Personal email ID: drkhalidmk70@gmail.com Department of Management Information Systems, College of Business, King Khalid University, Abha, Saudi Arabia 
To assess students' performance in an academic course, choosing appropriate assessment types, assessment methods, and assessment activities are very important (Süral, 2016). These assessment components have to be coherent with the course learnings (Light et al., 2009). Further, measuring the students' performance is equally vital in the quality improvement process (Baeten et al., 2013).

Ideas of the best practice in course evaluation and performance measurement have also started to emerge (Bradley et al., 2015). Kucsera \& Svinicki (2010) discussed the academic evaluation, emphasized quality assessment, and considered both systematic and result-orientation in an educational environment. Furthermore, identifying relevant key performance indicators (KPIs) for a course is significant in measuring students' course learning. An elaborative description of KPI will be found in Section 3.1. These indicators should be coherent to the course objectives and have the potential to measure students' performance of the course learning (Fernandes et al., 2014).

Indeed, KPIs assist teachers in measuring students' performance of course learning, and achieving its objectives (Mohiuddin, Rasool, et al., 2019). For course assessment using KPIs, a course teacher needs to determine course performance indicators and define KPIs for measuring students' performance (Sizer et al., 1992). Moreover, usually KPIs in rubric form (Mohiuddin, Rasool, et al., 2019) describe three levels of performance (see Table 3). Importantly, these KPIs are useful tools to measure course learning in a higher educational environment (Martin \& Sauvageot, 2011).

The course-KPIs must be measurable units and significant in measuring course learning performance. KPIs help in judgments and are the authoritative, qualitative, and quantitative measures of key attributes of the functions of an institution (Ramsden, 1991; University of Nottingham Malaysia, 2017). They are viewed as tools that undertake quality assurance, measure the effectiveness and efficiency of the processes to achieve institutional objectives (Bruwer, 1998). Higher education institutions use performance indicators for monitoring academic, institutional performance (Chan, 2015) and internal evaluative procedures (Ramsden, 1991). Brown (2012) suggested that determination of KPIs is one of the primary approaches of performance evaluation in higher education. These indicators are defined considering the course objectives and learning. Further, these KPIs have to be followed while assessing students' performance of the course learning. The measured performance outcomes help in getting the strengths and weaknesses of the students' performance. The result of outcomes also helps teachers realize how learning occurs (Pereira et al., 2016). Generally, KPIs evaluate the success of a particular activity in which it engages (Azma, 2011). Based on the performance outcomes, a summary report is prepared that includes the strengths, weaknesses, and suggested actions to improve the course learning. The suggested actions need to be considered in the next cycle of course delivery. Effective implementation of the suggested actions assures continuous improvement of course learning and also helps in achieving the desired learning objectives (Fernandes et al., 2014).

Significantly, the course measure outcomes are the indicators of the students' course learning. These outcomes precisely show the teachers the strengths and the weaknesses of the course performance and guidelines to improve learning in the next phase of the course delivery. Usually, teachers discuss the measured outcomes with the students after the assessment evaluation and performance measurement. Here, students get the opportunity to know both their performances and course learning abilities, such as their cognitive and interpersonal skills. Further, teachers give more attention to the students' weak areas, implement the suggested actions while delivering the course at the current and the next cycles. The students need to use the performance measurement results when planning their future course works. Importantly, the whole process guides the teachers and helps the students to improve teaching and learning. 
In the institutions with a centralized evaluation system, the primary aim of course assessment is to measure students' performance, analyze the performance outcomes, and implement the suggested actions of the course learning in the next delivery. Some evaluation systems are in place to improve the quality of education (Martin \& Sauvageot, 2011). Of the course assessment, the course evaluation outcomes are the end result and useful indicators that should be used wisely for the improvement of course learning, and the academic program the institution offers (Light et al., 2009).

The motivation for this work is the unavailability of a course assessment that integrates course associated components and considers the relationship between the learning domains and course learning. For an academic course, the possible components are Course Specification (CS), Course Report (CR), Program Learning Outcomes (PLOs), Program Specification (PS), learning domains, and course learning skills, and all these are associated coherently. The presented study applies a novel scientific approach to assess students' course leaning and measure their performance. This process also considers the learning domain which is logically corresponding to the course learning. Here, the learning domain, for instance "communication skills" is considered against the course learning. Innovatively, this study describes course-KPIs that are significantly used in measuring students' course learning performance (MercerMapstone \& Matthews, 2017).

In the process, we accessed literature available across the top-rated resources. To the best of authors'efforts, we didn't find any study which measures students' performance using courseKPIs (Mercer-Mapstone \& Matthews, 2017). This study applies a novel approach to assess students' course learning and measure their performance by applying scientific calculations. This process needs some precise documents which are associated with the course (Klenowski et al., 2006) and useful in evaluating students' course performance. Importantly, the outcomes of the performance measurement correlate with the predefined course learning objectives (CLOs) that determine the intended learning skills of the course (Strydom, 2017). Finally, the measured course outcomes are benchmarked with the outcomes of previous performance measured and new targets are set for the next cycle of course delivery. Indeed, the whole process of measuring course learning improves the quality of learning and teaching (Pereira et al., 2016).

\subsection{Contributions}

This study introduces an assessment approach that integrates students' assessments in an academic course, its components, and course performance measurement using course-KPIs for continuous improvement. The original contributions of this study are:

- The integrated assessment approach using course-KPIs (Section 3).

- Mapping between course learning, learning domains, and academic program learning outcomes (Table 1).

- A novel approach of course assessment (Section 3.1).

- Measuring students' performances using course-KPIs (Section 3.2).

- The study's approach can be adopted for any academic course and data size.

Apart from these the article comprises of Section 1 which explains the integration of course components and performance measurements in higher education, and the purpose of the study. Section 1.2 describes the study's aim and Section 2 presents the study's adopted methods. Finally, we present the study's findings and conclusions.

\subsection{Aim}

This study aims to integrate assessment and performance evaluation of students enrolled in an academic course. Significantly, the study also considers course associated components and the 
logical relation between course learning objectives (CCELT, 2020) with the program learning domain. At the beginning of the course delivery the authors decided to assess students' performance for communication skills of the course learnings and this is in accordance with the "communication skills" of the learning domain because the intended course learning objectives correlate with learning domain "communication skills".

For course assessment, this study measures students' performance using course-KPIs and analysis of the measured outcomes to determine the skills learned from the course contents (Pereira et al., 2016). Here, the assessment methods have to be relative to the course learning (Mohiuddin, Rasool, et al., 2019) and correspond to the learning domain (Mercer-Mapstone \& Matthews, 2017). For useful performance measurement, the course-KPIs are defined before the start of the course delivery and agreed on the assessment method. Figure 1 includes the components that are logically associated with the course. Further, based on the students' performance measurement, a summary report is developed that provides the strengths and weaknesses, and the recommended actions (see Table 6) which guide teachers in improving course learning (Pereira et al., 2016). Finally, the result of the performance measured is benchmarked with the previous result and new targets are set for the next performance measurement (see Table 7). This process increases provisions for the teachers in the process of continuous improvement (Strydom, 2017).

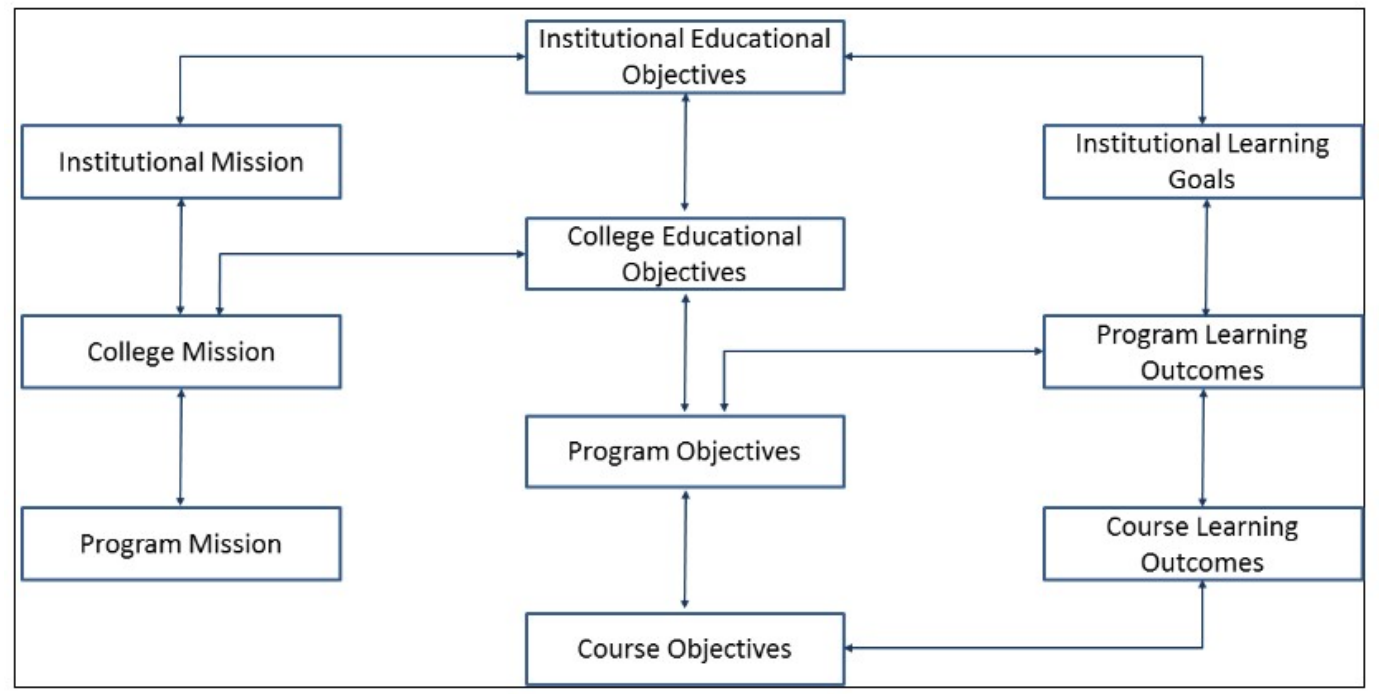

Figure 1. Coherent components for the performance evaluation of an academic course and a program in higher education.

Figure 1 describes the components which are associated logically when evaluating students' performance in an academic course of an academic program in higher education. This also shows the importance of other components in achieving course learning objectives. The course objectives are the fundamental learning that students attain at their course completion. The course learning skills and the program learning skills logically map the institutional learning goals, and finally the institutional objectives. These entities are coherent among and aligned together with the mission of the program, college, and institution.

\section{METHOD}

\subsection{Study Context}

The study's approach applies to measure students' outcome-based learning performance in an academic course at King Khalid University in Saudi Arabia in the spring semester, 2017- 2018 academic year. The selected three-credit-hour course is a core course and prerequisite to capstone projects of the Information Systems program that is offered in the sixth semester. The 
"Seminar" course bears the course code of "MIS492-3." This course's learning outcomes help students to be developed for their capstone projects, specifically in report writing and project presentation. The teaching schedule includes report writing skills of two credits and the oral presentation of one credit. During the course delivery, students participate in both formative and summative assessments. The course teachers measure students' performances against course learning outcomes using the predefined KPIs after each assessment. There are five CLOs of this course split into two groups of "oral presentation/presentation dynamics" and "writing skills."

In this case, students' oral presentation skills of the course content were measured using the defined KPIs. Importantly, course teachers developed these KPIs considering the CLOs approved by the stakeholders such as the academic committee, head of the department, and course coordinator of the department. For the assessment and quality improvement process, some predefined course associated documents were required

This study requires a more in-depth and specific literature review to make it relatable to the study's idea. During the literature review, it is found that various methods have been adopted to evaluate students' performance in academic courses in higher education (Pereira et al., 2016). We have found many studies which evaluate performance using KPIs for both business organization and higher educational institutions. John Sizer (1992) outlined the critical excellence of performance indicators in higher education for achieving desired results. Further, he precisely mentioned the role of performance indicators in higher education and considered them as quality assessment procedures. He also argued for the performance indicators that provide a variety of assessment in the educational system and consider comparative quality judgments. He concluded that political culture, educational funding system and the quality assessment procedures largely impact the role of performance indicators in higher education. Suryadi (2007) developed a framework on key success factors for measuring performance of higher education institutions. KPIs were focused on academic, research and supporting functions. The researcher conducted subjective evaluation using the Analytic Hierarchy Process (AHP) technique. On the other hand, performance indicators were used to measure the teaching performance in Australian Higher Education under a national trail (Ramsden, 1991). Student evaluation was designed using course experience questionnaire which was scored on a 5-point Likert-type scale and several types of analysis were conducted, i.e. item factor analysis, scale internal consistencies and scale validity. However, we couldn't find any study which integrates assessment, course associated components, and course-KPIs that are very useful in measuring students' performance of course learning. From the literature review, it is found that most of the studies are theoretical, and only a few studies are done by collecting the course assessment data. This study bridges the literature lacuna of this neglected area of research (Chan, 2015).

To the best of our efforts and access to the multiple resources (Alstete, 1995; Dawson, 2017; Gibbs, 2003; Haertel, 1999) during our study for course assessment, we couldn't find any specific study that relates our idea (Pereira et al., 2016). We have adopted a systematic approach to evaluate students' performance in the course during the course delivery. The course learning objectives motivate us to evaluate students' performance for the course learning skills along with the program learning skills in the corresponding learning domain. The performance evaluation result helps us to be more specific while delivering the course in the next cycle.

Generally, the maximum limit of students' enrollment for the selected course is twenty. In this case, twenty students were enrolled in the course for the spring semester, 2017. Seven students' enrollment was canceled because of not obeying the initial attendance rules. So, the study sample comprised of only thirteen students that is not big in size. Nevertheless, the study's approach can be used for any number of students and this study also has the potential for quality learning. The course was offered by a department at a Saudi University. All thirteen students 
participated in the course assessments during the semester. At the beginning of the course delivery, the teachers must consider the previous semester's course evaluation report (e.g., fall 2016), and the benchmarking for the current semester (see Table 7).

\subsection{Associated Components}

The students' performance data are gathered by the assessment results and the performance evaluation reports. The components which have been shown in Figure 1 contain the associated documents that are considered during course performance evaluation.

Participants: The participants are all the thirteen students, course-teacher, and course coordinator who are directly involved in the evaluation process.

\subsection{Associated Documents}

For the course delivery, some course-associated documents are required while evaluating and measuring students' performance.

Program specification (PS): It is a precise document that describes the intended learning outcomes of an academic program. It describes program learning skills that are explained through a certain number of PLOs, listed in Table 1. It also describes the curriculum, learning and assessment methods, and other information related to the program (NCAAA, 2012; QAAHE, 2017).

Course specification (CS): It is a prime document that has to be followed while delivering the course. It describes the aims and objectives of the course which covers teaching and assessment methods, and mapping between CLOs and PLOs (Strydom, 2017) and also includes the course evaluation and improvement process. CS should be prepared for all the courses offered in the program and has to be reviewed periodically. Course learning outcomes are statements that describe essential learning that learners have achieved and can reliably demonstrate at the completion of the course (Strydom, 2017). A number of CLOs are written for every course and listed in the CS that have to be mapped with any of the PLOs to correlate with the program learning skills (Sizer et al., 1992).

Course report (CR): A CR is an accumulated document that covers all the activities conducted for the course during the semester. It describes the course execution summary and the evaluation result. It also includes the issues in delivering the course and the suggested actions for the course improvement.

Rubrics: In an academic environment, rubric means a measuring tool used to check students' performance and the quality of their responses. Rubrics usually contain evaluative criteria, quality definitions for those criteria at particular levels of achievement, and a scoring strategy (Popham, 1997). They are often presented in the table format as shown in Table 3 and can be used by teachers when marking and by students when planning their work (Dawson, 2017).

\section{ASSESSMENT APPROACH}

For assessing students' performance in a course, it is essential to follow the assessment methods and assessment activities described in the course specification. Each course learning outcome listed in the course specification must have logical mapping, at least with one of the program learning outcomes (PLOs). In this case, it is for communication skill (PLO-D), as shown in Table 1. The assessment outcome(s) should be mapped to any of the PLOs, either D1 or D2. It also corresponds to ABET-code-f (ABET, 2017). 
Table 1. Twelve PLOs Distributed into Four Learning Domains

\begin{tabular}{lll}
\hline Learning domains with code & \multicolumn{1}{c}{ PLO code } & \multicolumn{1}{c}{ Corresponding ABET code } \\
\hline Knowledge (A) & A1, A2, and A3 & j, a, e \\
Cognitive skills (B) & B1, B2, B3, and B4 & i, k, c, b \\
Interpersonal skills (C) & C1, C2, and C3 & g, h, d \\
Communication skills (D) & D1 and D2 & f \\
\hline
\end{tabular}

Table 1 lists the twelve PLOs divided into four learning domains under the national qualification framework (NQF) (NCAAA, 2012). The program learning skills are represented into four learning domains by following the ABET guidelines (ABET, 2017). ABET is an international accreditation agency that accredits academic programs in computing and engineering (Mohiuddin, Islam, et al., 2019). So, we framed three PLOs (A1-A3) in the knowledge domain, (B1-B4) in cognitive skills, (C1-C3) in interpersonal skills, and (D1-D2) assigned for communication skills. Based on the course content, students' evaluation is done for communication skills that correspond to PLO-D2.

Table 2. Course Evaluation Description Describes at the Beginning of the Course

\begin{tabular}{clll}
\hline \multicolumn{1}{c}{ PLO code: D2 } & Level 3: Satisfactory & Level 2: Developing & Level 1: Unsatisfactory \\
\hline KPI name: Oral & A well-organized oral & Covers the required & Presentation is \\
presentation delivery & presentation covering \\
the required contents- & $\begin{array}{l}\text { contents but not } \\
\text { adequately, missing the } \\
\text { delivered effectively. }\end{array}$ & $\begin{array}{l}\text { organized poorly; } \\
\text { technical aspects and } \\
\text { flow. }\end{array}$ & $\begin{array}{l}\text { technical aspects of the } \\
\text { topic are presented. }\end{array}$ \\
\hline
\end{tabular}

Assessment method Oral presentation

Assessment activity Prepare a well-organized presentation on the technical topic from the course content. Demonstrate the technical aspects, the flow, and the presentation mechanics effectively.

Assessment type Individual and group - decided by the teacher

Table 2 describes the assessment framework and the performance indicator (KPI). In the table, the KPI name is 'Oral presentation delivery'. The students' performances have to be evaluated following the assessment method, type, and activity. The performance is assessed in three levels, 'satisfactory', 'developing', and 'unsatisfactory' as shown in Table 3.

\subsection{The Process}

The course-KPIs are listed in the course specification and should be used for the students' performance measurement. University of Nottingham Malaysia (2017) defined KPIs as the quantitative and qualitative measures used to review the institutional progress against its goals. KPIs' characteristics are realistic, representative, specific, attainable, measurable, and timely. Lord Kelvin (1889) truly said: "If you cannot measure it, you cannot improve it." Moreover, Taticchi et al. (2010) described performance measures as a metric to quantify the efficiency and effectiveness of an action. John Sizer (1992) believed that an indicator represents system performance.

During the course evaluation, measuring students' performance is an essential activity for course improvement (Pereira et al., 2016). The measured outcomes are the critical indicators that guide the teachers for future course delivery (Strydom, 2017). The outcomes provide benificial information which helps its stakeholders in improving the course, the program, and also policy decision making on quality improvement (Dochy et al., 2006).

Use of rubrics: Rubric is a name or heading under which something is classified by comparing particular objectives. Rubrics are developed for several academic activities (Haertel, 1999). Prins et al. (2017) figured the critical use of rubrics, developed it based on the manual of the 
American Psychological Association. They suggested that rubrics are effective assessment tools for both teachers and students. They further explained that rubrics are used to make students aware of what is expected, and students get familiar with the grading criteria. Another study (Mohiuddin, Rasool, et al., 2019) conducted a skill-centered assessment in an academic course based on the course-KPIs and rubrics.

Validity and reliability: Generally, the course-KPIs are developed by the teachers with the approval of the knowledge area head in the department. These KPIs and rubrics (see Table 3) are developed and documented well in advance to the course delivery and assessment process. Importantly, the intented course learning outcomes are considered to measure performance, i.e., validity, while developing these assessment tools, and they vary with course learning. The measured performance (obtained score) is monitored by the knowledge area head and program coordinator for the consistency and improvement in the course, i.e., reliability (Reddy \& Andrade, 2010). Every course has its own KPIs and rubrics that are developed, considering both course learning objectives and course learning skills (Martin \& Sauvageot, 2011).

Table 3. Course KPIs in the Form of Rubrics

PLO-D: An ability to communicate effectively with a range of audiences, from Table 1

PLO (D1): Demonstrate professional competence in written skills

PLO (D2): Communicate verbally with audiences in an effective way

\begin{tabular}{|c|c|c|c|}
\hline \multicolumn{4}{|r|}{ Level 1: Unsatisfactory } \\
\hline $\begin{array}{l}\text { KPI-1) } \\
\text { Demonstrate } \\
\text { understanding } \\
\text { of presentation } \\
\text { dynamics }\end{array}$ & $\begin{array}{l}\text { Plans and delivers an } \\
\text { oral presentation } \\
\text { effectively; applies the } \\
\text { principle of "tell them" } \\
\text { well }\end{array}$ & $\begin{array}{l}\text { Presents key elements of } \\
\text { an oral presentation } \\
\text { adequately, but "tell } \\
\text { them" not clearly applied }\end{array}$ & $\begin{array}{l}\text { Talk is poorly organized; } \\
\text { no clear introduction or } \\
\text { summary of the talk is } \\
\text { presented }\end{array}$ \\
\hline $\begin{array}{l}\text { (KPI-2) } \\
\text { Organize } \\
\text { presentation } \\
\text { considering } \\
\text { audience and time } \\
\text { constraint }\end{array}$ & $\begin{array}{l}\text { Presentation has enough } \\
\text { detail and appropriate } \\
\text { content for the time } \\
\text { constraint and the } \\
\text { audience }\end{array}$ & $\begin{array}{l}\text { Presentation contains } \\
\text { excessive or insufficient } \\
\text { detail for the time allowed } \\
\text { or level of audience }\end{array}$ & $\begin{array}{l}\text { Presentation is } \\
\text { inappropriately short or } \\
\text { excessively long; omits } \\
\text { key results during the } \\
\text { presentation }\end{array}$ \\
\hline $\begin{array}{l}\text { (KPI-3) } \\
\text { Use appropriate } \\
\text { technical content }\end{array}$ & $\begin{array}{l}\text { Presentation has } \\
\text { appropriate technical } \\
\text { content for the time } \\
\text { constraint and the } \\
\text { audience }\end{array}$ & $\begin{array}{l}\text { Presentation contains } \\
\text { excessive or insufficient } \\
\text { technical detail for the } \\
\text { time allowed or level of } \\
\text { audience }\end{array}$ & $\begin{array}{l}\text { Presentation is technically } \\
\text { inappropriate; omits key } \\
\text { results during a } \\
\text { presentation }\end{array}$ \\
\hline $\begin{array}{l}\text { (KPI-4) } \\
\text { Show linguistic } \\
\text { command orally }\end{array}$ & $\begin{array}{l}\text { Uses proper American } \\
\text { English }\end{array}$ & $\begin{array}{l}\text { Occasionally uses an } \\
\text { inappropriate style of } \\
\text { English. }\end{array}$ & Uses poor English \\
\hline $\begin{array}{l}\text { (KPI-5) } \\
\text { Illustrate ideas } \\
\text { using effective } \\
\text { visual aides }\end{array}$ & $\begin{array}{l}\text { Uses visual aids } \\
\text { effectively }\end{array}$ & $\begin{array}{l}\text { Visual aides have minor } \\
\text { errors or are not always } \\
\text { clearly visible }\end{array}$ & $\begin{array}{l}\text { Multiple slides are } \\
\text { unclear or } \\
\text { incomprehensible }\end{array}$ \\
\hline
\end{tabular}

Table 3 represents the sample of five KPIs (1-5) defined and documented for the students' performance measurement in the course. The PLO-D is one of the program learning skills listed in Table 1. D1 and D2 are program learning outcomes split under D. These KPIs correspond to the learning domain-D, i.e., communication skills from Table 1. Each KPI, with its code (1-5), is listed in the first column and is explained into three levels of performance. Level 3 describes the performance standard 'satisfactory', level 2 'developing', and level 1 'unsatisfactory'.

Table 4 represents the sample of a single student's performance in all the KPIs (1-5) in the course assessment. It also shows the performance levels (L), described as 'S-satisfactory,' 'D- 
developing,' and 'U-unsatisfactory,' and $(\checkmark)$ is the obtained performance by the student. Similarly, the data is collected for all the thirteen students shown in Table 5.

Table 4. Sample of Single Student's Performance in the Course Assessment

\begin{tabular}{|c|c|c|c|c|c|c|}
\hline \multicolumn{4}{|c|}{ University ID: 433822625} & \multicolumn{3}{|c|}{ Course code: $\quad$ ISM492 } \\
\hline \multicolumn{4}{|c|}{ Student name: Our student } & \multicolumn{3}{|c|}{ Course name: Seminar } \\
\hline Semester: & II, Spring 2017 & & & Section number: & 1351 & \\
\hline \multicolumn{7}{|c|}{ CLOs correspond to PLO-D2 } \\
\hline$\overline{\text { KPI-code }(1-5)}$ & KPI-1 & & KPI-2 & KPI-3 & KPI-4 & KPI-5 \\
\hline levels $(L)$ & $\mathrm{D}$ & $\mathrm{S}$ & $\mathrm{D}$ & $\mathrm{D}$ & $\mathrm{D}$ & $\mathrm{D}$ \\
\hline Obtained & $\checkmark$ & & $\checkmark$ & $\checkmark$ & $\checkmark$ & $\checkmark$ \\
\hline
\end{tabular}

\subsection{Measuring the performance}

Measuring the students' performance of the course assessment is possible only when the KPIs are realistic, achievable, and measurable. These students' performances are measured on their attempt in the course assessment. The level of students' performance $(1,2$ or 3$)$ decides on students' gain for each KPI, defined in Table 3 and the sample is shown in Table 4.

Table 5. Students' Performance Measured for KPIs (1-5) for Thirteen Students

\begin{tabular}{lccccc}
\hline PLO-D2 & $\begin{array}{c}\text { Level 3: }\left(l_{3}\right) \\
\text { KPI Nos. }\end{array}$ & $\begin{array}{c}\text { Level 2: }\left(l_{2}\right) \\
\text { Satisfactory }\end{array}$ & $\begin{array}{c}\text { Level 1: }\left(l_{1}\right) \\
\text { Unsatisfactory }\end{array}$ & $\begin{array}{c}N \text {-Total } \\
\text { Number }\end{array}$ & $\begin{array}{c}\text { KPI performance } \\
\text { out of 5 }\end{array}$ \\
\hline D2. (1-5) & $n_{1}=03$ & $n_{2}=04$ & $n_{3}=06$ & $N=13$ & 2.948 \\
\hline
\end{tabular}

Table 5 shows the average of students' performance data for all the thirteen students who participated in the assessment and the result of KPIs (1-5) measurement. Levels $(l 1-l 3)$, show the students' performance level in the assessment. These performances are measured using rubrics (from Table 3) and ranked into three groups: satisfactory $\left(n_{1}=03\right)$, developing $\left(n_{2}=04\right)$, and unsatisfactory $\left(n_{3}=06\right)$.

$K P I=\frac{\left(n_{1} * l_{3}\right)+\left(n_{2} * l_{2}\right)+\left(n_{3} * l_{1}\right)}{(\mathrm{L} * \mathrm{~N})} * \mathrm{PS}$

Where $n_{1}, n_{2}, n_{3}$, are the three groups of students based on performance $l_{1}, l_{2}, l_{3}$, are the three different levels of performance

$P S$, is the performance scale on 5

$L$, is the number of performance levels, i.e., 3

$N$, is the total number of students

$\mathrm{KPI}=\frac{(3 * 3)+(4 * 2)+(6 * 1)}{(3 * 13)} * 5$, by applying equation $(1)$

$\mathrm{KPI}=\frac{115}{39}=2.948$

Table 6 describes the result of students' performance and the teacher's comments. '2.948' is the overall students' performance on scale 5. The evaluator has suggested some actions to be initiated to improve the performance before the next delivery of the course. 
Table 6. The Overall Students' Evaluation Summary Written in Course Report (CR)

\begin{tabular}{cccccc}
\hline $\begin{array}{c}\text { PLO-D - KPI } \\
\text { numbers }\end{array}$ & $\begin{array}{c}\text { Level 3: }\left(l_{3}\right) \\
\text { Satisfactory }\end{array}$ & $\begin{array}{c}\text { Level 2: }\left(l_{2}\right) \\
\text { Developing }\end{array}$ & $\begin{array}{c}\text { Level 1: }\left(l_{1}\right) \\
\text { Unsatisfactory }\end{array}$ & $\begin{array}{c}\text { N-Total } \\
\text { Numbers }\end{array}$ & $\begin{array}{c}\text { Performance } \\
\text { on scale 5 }\end{array}$ \\
\hline$(1-5)$ & 3 & 4 & 6 & 13 & 2.948 \\
\hline
\end{tabular}

Observations:

A few students can organize the presentation correctly.

Some students could not organize the content properly.

Recommendations:

Most of the students should understand the presentation mechanics.

Some of the students should learn the organization of topics in the context.

A few students considerably should learn the presentation skills.

\section{Actions:}

Conduct some sessions on presentation skills.

Students should be sent to the language center to improve their communication skills.

\subsection{Analysis}

The total number of students are categorized into three performance groups from grade points 100:

- Group ' $n_{1}=03$ ' is graded as 'satisfactory' and their overall share is ' $23.07 \%$ '.

- Group ' $n_{2}=04$ ' is graded as 'developing' and their overall share is ' $30.77 \%$ '.

- Group ' $n_{3}=06$ ' is graded as 'unsatisfactory' and their overall share is ' $46.15 \%$ '.

Meaningful outcomes: The teachers translate the obtained numerical values into meaningful outcomes by following Table 3 and 6 . The same result is shown graphically in Figure 2.

- '23.07\%' students have presented the concept, organized presentation in the context, and gave presentation convincingly.

- ' $30.77 \%$ ' students have covered the topic but not in an adequate way, and the presentation was not convincing.

- ' $46.15 \%$ ' students were unable to organize the presentation in the context. Even the concept in the topic was not clear.

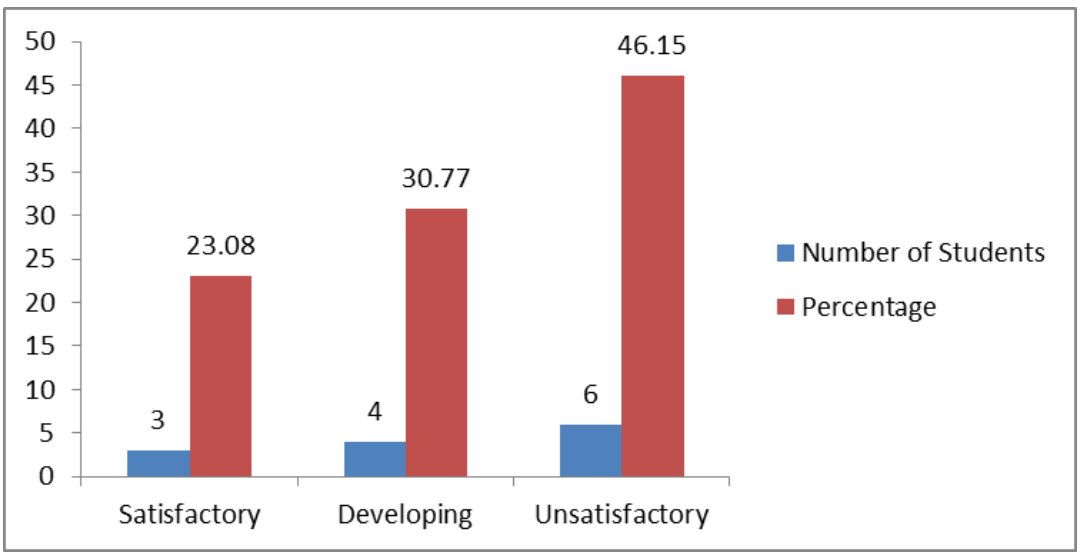

Figure 2. Students' performance measured using KPIs out of 100 grade points.

\subsection{Course Improvement Plan}

The students' performance records are kept into a formal document called 'course report-CR'. This CR is the executed summary of the course specification. The teachers preserve the assessments' record for the future practices. Based on the performance outcomes, a course quality improvement plan develops. The course coordinator monitors the assessments' process and checks the possibilities to implement the suggested actions before the next course delivery. 
Effective implementation of the suggested actions assures quality improvement in the course delivery and learning.

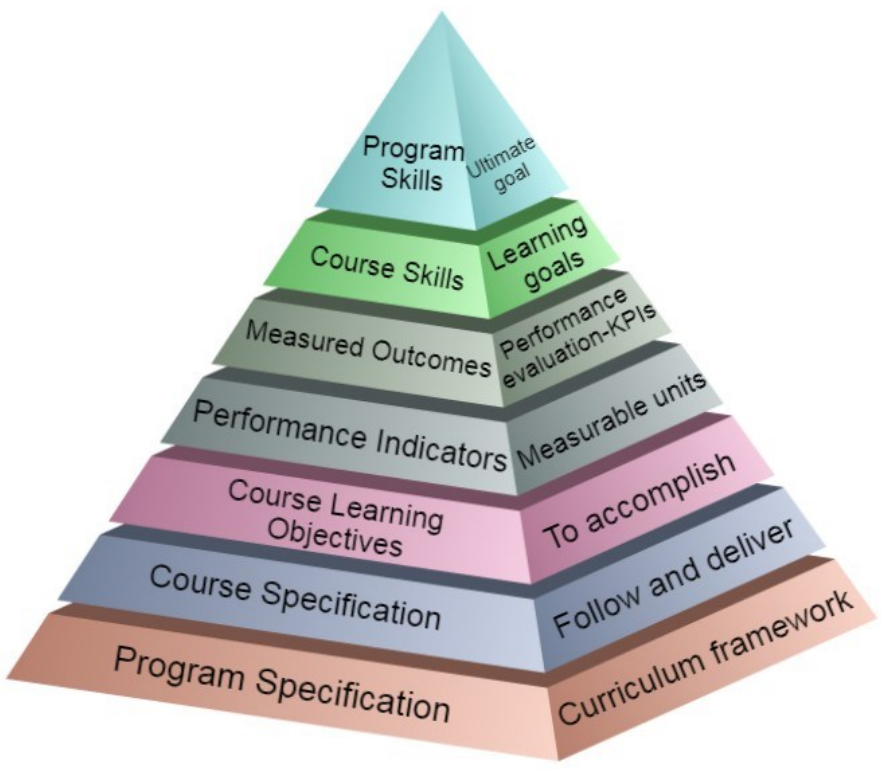

Figure 3. The bottom-up approach and associated entities of an academic course in higher education.

Figure 3 shows the coherent entities that need to be considered when evaluating students' performance in an academic course. The process begins referring to the program specification, executing course specifications, and ends-up when the students' performance is measured. During the process, these coherent entities must be followed to achieve all the learning skills. The evaluation result indicates that the skills are learned by the students and demonstrates the accomplishment of program skills. The evaluation process is implemented for every single course offered from the curriculum of the academic program. Surely, this achieves both learning objectives and quality teaching.

\subsection{Benchmarking}

Benchmarking has been emerged as a useful tool for staying competitive (Alstete, 1995). The strategy of benchmarking is significant and is being used as an instructional model in academic institutions to improve quality (Alstete, 1995). Stakeholders in higher education have realized the increasing importance of benchmarking for continuous improvement.

In this approach, the performance evaluation result is benchmarked with the previous performance result of the course. This will increase the option of implementing a course improvement plan before the next course delivery. Also, this helps in the process of continuous improvement of course learning and teaching.

Table 7. Benchmarking the Overall Students' Performance Measured in the Course

\begin{tabular}{|c|c|}
\hline CLOs map to PLO-D (A & to communicate effectively with a range of audiences) \\
\hline $\begin{array}{l}\text { Assessment year: spring } \\
\text { in Table } 3 \text {. }\end{array}$ & r, 2017. Course learning skills map to PLO-D1 and D2, as shown \\
\hline $\begin{array}{l}\text { Learning domain } \\
\end{array}$ & Communication skill \\
\hline Target benchmark & 3.5 - was set for spring semester, 2017 \\
\hline Measured performance & $2.948-$ is achieved for spring semester, 2017 \\
\hline Internal benchmark & $3.5-$ was set by the authority for spring semester, 2017 \\
\hline External benchmark & 4.0 and above, set by external advisory board \\
\hline New target benchmark & 3.25 - set by the coordinator for fall semester, 2017 \\
\hline
\end{tabular}


Table 7 describes the benchmarking of the students' performance measurement of the learning skills in the course assessment. The first column shows different benchmarking fields and the corresponding values in the second column.

\subsection{Key issues}

Klenowski et al. (2006) highlighted the issues of effective learning and portfolio used in higher education and Pedrosa de Jesus (2009) explained the assessment methods, issues that were aligned with teaching and learning. Our study follows some specific documents that describe activities to be followed for the course delivery. The main issue is to develop these documents during the course delivery under NQF (ETEC, 2018) in Saudi Arabia. Subsequently, maintaining the course evaluation reports is critical for the stakeholders in every semester. Further, the study follows ABET guidelines for measuring the skills learned from the course content (ABET, 2017). The other key issue is that the process has to be followed more effectively on each cycle of the course delivery.

\section{CONCLUSION}

This study facilitates to minimize the gap between the unavailability of good number of research and useful study on measuring student performance using course-KPIs in higher education. This process helps in achieving course learning objectives and program learning skills that are the prime aspects of this study. Skilled graduates can be produced by measuring the students' performance of the courses offered in the academic program.

Most of the existing assessment methods are course learning oriented. This study demonstrates a novel approach to measure and assess students' course learning skills by applying courseKPIs exemplifying scientific calculations. Teachers will find those calculations convenient to measure their learners' achievement. Though this study uses KPIs and relevant rubrics to show a single skill namely 'Communication Skills,' other skills surely can be modeled upon this KPIs to measure effectively the skills performance.

Moreover, the performance evaluation result indicates the strengths and weaknesses of the students' performance. This result also guides the teachers in preparing course improvement plan on continuous improvement. This study presents the diagraming among course learning, learning domains, and academic program learning outcomes keeping KPIs at the center to guide the whole assessment and evaluation process. It also helps in identifying how to measure students' performance using rubrics. The correlation between course evaluation and its components, and benchmarking are the great significance of this study. Indeed, this provides a suitable direction to the teachers for quality teaching. The approach demonstrated in this study can be adopted for any academic course in higher education irrespective of the number of participating students.

Finally, the presented study assures that the quality improvement in teaching-learning by following the approach will be enhanced. Future research with this approach is undoubtedly adaptable for any academic course with different sample sizes in higher education. Indeed, by following this approach, the study's validity and effectiveness can be compared in any state or region. Significantly, educators get a fair picture by practicing this assessment approach and a significant change in the quality improvement process. 


\section{Declaration of Conflicting Interests and Ethics}

The authors declare no conflict of interest. This research study complies with research publishing ethics. The scientific and legal responsibility for manuscripts published in IJATE belongs to the author(s).

\section{ORCID}

Khalid MOHIUDDIN (D) https://orcid.org/0000-0001-7531-4512

Mohammad Aminul ISLAM (iD https://orcid.org/0000-0001-8269-2394

Shahrear TALUKDER (D) https://orcid.org/0000-0002-9840-4139

Mohammed ALGHOBIRI (id https://orcid.org/0000-0002-6414-739X

Mohamed Nadhmi MILADI (iD) https://orcid.org/0000-0002-9862-0034

Ahmed Abdelmotlab AHMED (iD https://orcid.org/0000-0002-4363-8261

\section{REFERENCES}

ABET (2017). Criteria for Accrediting Computing Programs, 2016 2017. ABET. https://www. abet.org/accreditation/accreditation-criteria/criteria-for-accrediting-computing-programs -2016-2017/

Alstete, J. W. (1995). Benchmarking in Higher Education: Adapting Best Practices to Improve Quality. ERIC Development Team. http://files.eric.ed.gov/fulltext/ED402800.pdf

Aoudia, M., Marji, K., \& AlQahsi, D. A.-D. (2015). Assessment of Higher Education Quality by Using Cohort of First-year in University. Procedia - Social and Behavioral Sciences, 191, 330-335. https://doi.org/10.1016/j.sbspro.2015.04.310

Azma, F. (2011). The Quality Indicators of Information Technology in Higher Education. Procedia - Social and Behavioral Sciences, 30, 2535-2537. https://doi.org/10.1016/j.sbs pro.2011.10.494

Baeten, M., Struyven, K., \& Dochy, F. (2013). Student-centred Teaching Methods: Can They Optimise Students' Approaches to Learning in Professional Higher Education? Studies in Educational Evaluation, 39(1), 14-22. https://doi.org/10.1016/j.stueduc.2012.11.001

Bradley, K. D., Snyder, E. M., \& Tombari, A. K. (2015). Higher Education End-of-Course Evaluations: Assessing the Psychometric Properties Utilizing Exploratory Factor Analysis and Rasch Modeling Approaches. International Journal of Assessment Tools in Education, 3(1). https://ijate.net/index.php/ijate/article/view/90

Brown, C. (2012). Application of the Balanced Scorecard in Higher Education Opportunities and Challenges. Society for College and University Planning, 40(4), 40-50.

Bruwer, J. (1998). First Destination Graduate Employment as Key Performance Indicator: Outcomes Assessment Perspectives. Journal of Institutional Research in Australasia, 8(2), 61-91. http://www.aair.org.au/app/webroot/media/pdf/AAIR Fora/Forum1998/Bruwer.pdf

CCELT. (2020). Writing Course Goals/Learning Outcomes and Measurable Learning Objectives. Iowa State University. https://www.celt.iastate.edu/teaching/preparing-toteach/tips-on-writing-course-goalslearning-outcomes-and-measur

Chan, V. (2015). Implications of Key Performance Indicator Issues in Ontario Universities Explored. Journal of Higher Education Policy and Management, 37(1), 41-51. https://doi.org/10.1080/1360080X.2014.991531

Dawson, P. (2017). Assessment Rubrics: Towards Clearer and More Replicable Design, Research and Practice. Assessment \& Evaluation in Higher Education, 42(3), 347-360. https://doi.org/10.1080/02602938.2015.1111294

Dochy, F., Segers, M., \& Sluijsmans, D. (2006). The Use of Self-, Peer and Co-assessment in Higher Education: A Review. Studies in Higher Education, 24(3), 331-350. https://doi.org/10.1080/03075079912331379935 
Douglas, E. M., \& Hines, D. A. (2011). The Helpseeking Experiences of Men Who Sustain Intimate Partner Violence: An Overlooked Population and Implications for Practice. Journal of Family Violence, 26(6), 473-485. https://doi.org/10.1007/s10896-011-9382-4

ETEC. (2018). National Framework for Public Education Curricula Standards. Education and Training Evaluation Commission. https://etec.gov.sa/en/productsandservices/NCSEE/C evaluation/Pages/NATIONALFRAMEWORK-.aspx

Fernandes, S., Mesquita, D., Flores, M. A., \& Lima, R. M. (2014). Engaging Students in Learning: Findings from a Study of Project-led Education. European Journal of Engineering Education, 39(1), 55-67. https://doi.org/10.1080/03043797.2013.833170

Gibbs, C. (2003). Explaining Effective Teaching: Self-efficacy and Thought Control of Action. The Journal of Educational Enquiry, 4(2). https://www.ojs.unisa.edu.au/index.php/EDE $\mathrm{Q} /$ article/view/520/0

Haertel, E. H. (1999). Performance Assessment and Education Reform. Phi Delta Kappan, 80(9), 662. https://www.questia.com/library/journal/1G1-54618911/performanceassessment-and-education-reform

Klenowski, V., Askew, S., \& Carnell, E. (2006). Portfolios for Learning, Assessment and Professional Development in Higher Education. Assessment \& Evaluation in Higher Education, 31(3), 267-286. https://doi.org/10.1080/02602930500352816

Kucsera, J. V., \& Svinicki, M. (2010). Rigorous Evaluations of Faculty Development Programs. The Journal of Faculty Development, 24(2), 5. https://eric.ed.gov/?id=EJ897466

Light, G., Cox, R., \& Calkins, S. (2009). Learning and Teaching in Higher Education: The Reflective Professional. Sage Publications Ltd. https://books.google.com.sa/books?id=B DtdBAAAQBAJ\&source $=\mathrm{gbs}$ book other versions

Martin, M., \& Sauvageot, C. (2011). Constructing an Indicator System or Scorecard for Higher Education: A Practical Guide. In Intenational Institute for Educational Planning. http://uis.unesco.org/sites/default/files/documents/constructing-an-indicator-system-orscorecard-for-higher-education-a-practical-guide-2011-en.pdf

Mercer-Mapstone, L. D., \& Matthews, K. E. (2017). Student Perceptions of Communication Skills in Undergraduate Science at an Australian Research-intensive University. Assessment and Evaluation in Higher Education, 42(1), 98-114. https://doi.org/10.1080/ $\underline{02602938.2015 .1084492}$

Mohiuddin, K., Islam, A., Mohd, S., \& Shariff, M. (2019). Evaluation of an Academic Program: The Case of Computing Accreditation Commission Framework in Higher Education. International Journal of Emerging Technologies in Learning, 14(11), 70-91. https://online-journals.org/index.php/i-jet/article/view/10178/5719

Mohiuddin, K., Rasool, A. M., Mohd, M. S., \& Mohammad, R. H. (2019). Skill-Centered Assessment in an Academic Course: A Formative Approach to Evaluate Student Performance and Make Continuous Quality Improvements in Pedagogy. International Journal of Emerging Technologies in Learning, 14(11), 92-106. https://onlinejournals.org/index.php/i-jet/article/view/10275/5720

NCAAA, S. A. (2012). National Commission for Academic Accreditation and Assessment Handbook for Quality Assurance and Accreditation in Saudi Arabia, Part 1-The System for Quality Assurance and Accreditation. NCAAA. http://www.kfupm.edu.sa/deanships/ dad/Documents/AAC/NCAAA Documents/H1. Handbook Part 1.pdf

Pedrosa de Jesus, H. (2009). The Role of Students' Questions in Aligning Teaching, Learning and Assessment: A Case Study from Undergraduate Sciences. Assessment \& Evaluation in Higher Education, 34, 193-208. https://doi.org/10.1080/02602930801955952

Pereira, D., Flores, M. A., \& Niklasson, L. (2016). Assessment Revisited: A Review of Research in Assessment and Evaluation in Higher Education. Assessment \& Evaluation in Higher Education, 41(7), 1008-1032. https://doi.org/10.1080/02602938.2015.105523 
$\underline{3}$

Popham, W. J. (1997, October). What's Wrong-and What's Right-with Rubrics. Educational Leadership, 72-75. http://www.ascd.org/publications/educational-leadershi p/oct97/vol55/num02/What's-Wrong-and-What's-Right-with-Rubrics.aspx

Prins, F. J., de Kleijn, R., \& Tartwijk, J. van. (2017). Students' Use of a Rubric for Research Theses. Assessment \& Evaluation in Higher Education, 42(1), 128-150. https://doi.org/10.1080/02602938.2015.1085954

QAAHE. (2017). Guidelines for Preparing Programme Specifications. In The Quality Assurance Agency for Higher Education. https://www.tsu.ge/data/file db/qa docs/guide lines for programme specifications.pdf

Ramsden, P. (1991). A Performance Indicator of Teaching Quality in Higher Education: The Course Experience Questionnaire. Studies in Higher Education, 16(2), 129-150. https://doi.org/10.1080/03075079112331382944

Reddy, Y. M., \& Andrade, H. (2010). A Review of Rubric Use in Higher Education. Assessment \& Evaluation in Higher Education, 35(4), 435-448. https://doi.org/10.1080/0260293090 $\underline{2862859}$

Sizer, J., Spee, A., \& Bormans, R. (1992). The Rôle of Performance Indicators in Higher Education. Springier-Higher Education, 24(2), 133-135. https://link.springer.com/conte nt/pdf/10.1007/BF00129438.pdf

Strydom, F. (2017). Higher Education Learning Outcomes Assessment: International Perspectives. Assessment \& Evaluation in Higher Education, 42(3), 492-494. https://doi.org/10.1080/02602938.2016.1139097

Süral, S. (2017). The Development Study of Thoughts Scale Towards Measurement and Assessment Course on High Education. International Journal of Assessment Tools in Education, 4(1), 79-95. https://dergipark.org.tr/en/pub/ijate/issue/23899/270300

Suryadi, K. (2007). Framework of Measuring Key Performance Indicators for Decision Support in Higher Education Institution. In Journal of Applied Sciences Research, 3(12), 16891695

Taticchi, P., Tonelli, F., \& Cagnazzo, L. (2010). Performance Measurement and Management: A Literature Review and a Research Agenda. Measuring Business Excellence, 14(1), 4 18. https://doi.org/10.1108/13683041011027418

University of Nottingham Malaysia. (2017). Key Performance Indicators. University of Nottingham Malaysia. https://www.coursehero.com/file/p18pg87/PROS-1010-Guidelin e-3-Key-Performance-Indicators-State-of-Victoria-2010-Version/

University of Technology Sydney. (2010). Seven Propositions for Assessment Reform in Higher Education. In Australian Learning \& Teaching Council. https://www.uts.edu.au/ sites/default/files/Assessment-2020_propositions_final.pdf 